\title{
12 Revolting against the established book market
}

\author{
Book cafes as key actors within the \\ counterpublic of the Scandinavian \\ New Left
}

Ragni Svensson

The complex relationship between the New Left student movement and the media has been highlighted and thoroughly analysed by several researchers of contemporary history. As shown in studies of the movement in Western Europe and the United States, its activists found themselves in a particularly intricate and symbiotic relationship with contemporary mass media, which were both appealed and appalled by its theatrical and photogenic elements. ${ }^{1}$ Media historian Kathrin Fahlenbrach argues that the political activism of the New Left brought along a new conception of the public. She suggests that the "counterpublic" constituted by this movement was characterised by a novel kind of interactivity, where co-determination represented an important building stone. Through the organisation of mass demonstrations, "sit-ins", or other visual performances attracting television and newspaper photographers, the movement was sometimes even capable of using traditional media as its messenger. ${ }^{2}$

In the Swedish television broadcast Direkt from November 1972, a reporter paid a visit to the Book Cafe in Lund, a bookshop in a university town in the south of Sweden. As the television camera zoomed in on long-haired youths in leather coats, intensely studying the political theory section of numerous bookshelves and surrounded by dim cigarette smoke and quiet protest songs, a narrator told the story of the venue. It was described as a successful example of the new, specialised bookshop that arose as a consequence of the deregulations of the Swedish book market in 1970, as well as an important meeting place for the political orientation, media consumption, and knowledge acquisition of Lund's younger inhabitants. ${ }^{3}$

The Book Cafe in Lund was part of a larger phenomenon of left-wing bookshops and book cafes emerging in Western Europe during the late 1960s and early 1970s. ${ }^{4}$ As a result of conditions that were both political and cultural, and dependent on processes in the national book markets, these venues were soon to achieve a foothold as information centres within the Scandinavian New Left movement.

In 1968, Scandinavia's first book cafe, Gamma in Stockholm, was launched by people on the editorial board of the New Left journal Zenit, in collaboration with members of the organisation Young Philosophers. The venues combined 
the manufacture and sale of different kinds of leftist media with a wide range of social activities. Books in multiple languages from publishers such as Modtryk in Copenhagen, Cavefors in Lund, Éditions Maspero in Paris, and Suhrkamp in Frankfurt coexisted with journals such as New Left Review and records from new "progressive" labels producing protest music. In the adjoining cafeterias, people were meant to come together, converse, contemplate, or read when the space was not used for poetry readings or study circles on different topics.

There were different kinds of book cafes. Some of them, often tiny cellar bookshops with limited opening hours, were directly associated with one of the party factions of the shattered left-wing movement, while others were independent of both political organisations and public or private funding. ${ }^{5}$ This chapter focuses on the latter group of independent Scandinavian socialist book cafes through an analysis of three different venues: two Swedish and one Danish. The book cafes in Lund, Stockholm, and Aarhus were all important actors within a Scandinavian network of socialist book cafes, each in its own way. Even though they differed in size, ambition, and outreach, the three cafes had much in common, not least in their view of knowledge dissemination.

The Book Cafe in Lund, the largest and best-known of the three, was established in 1970, with the aforementioned Gamma in Stockholm serving as a model. Gamma was only active for a few years but was replaced by the much larger book cafe Morianen ("Blackamoor") in 1973. Morianen, which had an orientation similar to that of its predecessors, was located on Drottninggatan, a street in central Stockholm. My Danish example, Aarhus Book Café, was launched in 1972 and was inspired by the Book Cafe in Lund and similar cafes in Copenhagen.

In this chapter, I analyse the book cafes as constituting parts of a counterpublic, in which a circulation of public knowledge, formulated and mediated within the New Left, was adapted within a Scandinavian context. How, and by which means, was this circulation constituted? Which kind of knowledge was favoured here, and how was it formulated and advocated?

I look upon the book cafes as key actors within this circulation and argue that they formed important links in several networks made up of similar actors, producers, as well as distributors of print and other media. Serving as mediators, marketers, and manufacturers of different kinds of media material, while simultaneously presenting a scene for meetings and other outward-facing activities, I consider them pivotal to the knowledge cycle of the historical context known as the New Left. The New Left can be defined as a loosely connected, extra-parliamentary mass movement descended from academic social sciences and humanities and gradually attaining an ever-greater public impact. ${ }^{6}$ It is my belief that an in-depth study of these enterprises can help us reach a better understanding of the ways in which a certain kind of public knowledge has been transferred, communicated, and applied historically within alternative political movements, as well as with regard to society.

The study constituting this chapter is based on empirical materials of varying character, which have been collected from a number of locations. Archival 
material, such as bulletins, mimeographed leaflets, and protocols from the three book cafes, has been collected from archives and university libraries in Sweden and Denmark, as well as from former activists at the book cafes. In addition, I have carried out interviews with some of these activists. In order to trace their impact on a larger, societal level, I have also analysed material from traditional media, such as television broadcasts and newspaper articles and reports concerning the book cafes, such as the one mentioned at the beginning of the chapter.

\section{Public knowledge, counterpublics, and knowledge actors}

Knowledge historian Philipp Sarasin has defined his subject matter as "the order of the more or less rational knowledge". 7 This clearly captures the form of knowledge that is at the heart of this study. My main interest is in what Simone Lässig refers to as "the transfer and application of knowledge produced in academia". 8 Such studies have mainly been carried out by historians of science and technology, but, just like Lässig, I argue for a similar approach in studies on the production and transfer of knowledge originating from social sciences and humanities, as was the case with regard to the Scandinavian book cafes presented here. ${ }^{9}$ The core ideas of the New Left originated in Western academia and were treated as actual facts by some of their advocates; however, they represented a kind of knowledge that was both normative and dependent on context.

The concept of "societal knowledge circulation" has been singled out as a means for focusing on the ways in which knowledge is created, transformed, and reshaped in an ongoing exchange between agents and institutions at different levels of society. ${ }^{10}$ In this process, knowledge becomes a kind of "public property" instead of the exclusive possession of a certain individual or group. ${ }^{11}$

Johan Östling and David Larsson Heidenblad identify the book market as a system that, due to its intrinsic structure and general reach, has a certain relevance to the study of societal knowledge circulation. ${ }^{12}$ They also emphasise how the notion of circulation as an essential part of knowledge production indicates a new interest in the invisible actors who together serve as a kind of engine in these processes. ${ }^{13}$

In an influential article from 1990, Nancy Fraser re-considers Jürgen Habermas's famous conception of the public sphere and shows how a plethora of counterpublics has always existed in conflict with the hegemonic public sphere. These counterpublics have worked as discursive arenas that "contested the exclusionary norms of the bourgeois public, elaborating alternative styles of political behaviour and alternative norms of public speech". ${ }^{14}$ There is an obvious link to the circulation of public knowledge monitored by the book cafes, as well as within the New Left movement on the whole. A key aspect of this circulation was the conviction that one stood for, and realised, a set of alternative ways of thinking and doing politics, which was directed both inwards and outwards. It was partly intended for a smaller group of already committed people and partly aiming to influence society at large. 
One of the most palpable ways of implementing the ideas of the New Left counterpublic was through the production and dissemination of different kinds of printed matter. In his study on American underground newspapers in the late 1960s, John McMillian emphasises how such newspapers played a vital role in the cultivation of a novel "movement culture" and a sense of commitment amongst the New Left in the United States. Instead of focusing on the influential and thoroughly studied American student organisations, such as Students for a Democratic Society (SDS), McMillian shows that grassroots media producers and distributers, even those working on a very small scale, had a great impact on the direction of the development of this movement. ${ }^{15}$ I adopt a perspective similar to that of McMillian, as I look upon the activists behind the book cafes as important knowledge actors in the context of public knowledge circulation within the counterpublic of the Scandinavian New Left.

\section{The emergence of an alternative book and media market}

It was really a political necessity to start the book cafe. A collective force was needed for the various political movements that Aarhus, Denmark - and Sweden! - was full of. This is hard to grasp today, but back then there were political movements almost everywhere.

They needed a place to reach out with their information material and others had a need to find it. And then the new alternative publishers emerged, and they also needed a channel for [their printed matter]. This is where the necessity arose, in the overall context we used to call counterculture. ${ }^{16}$

In an interview with two former activists at Aarhus Book Cafe, one of them expressed that the venue, as was also the case with corresponding activities in both Denmark and Sweden, was initiated as a reaction to an emerging need within the New Left movement in his hometown. As he described it, the various activist groups that made up the Danish New Left, as well as leftist publishers and presses, that saw the light of day at the end of the 1960s and the beginning of the 1970s needed platforms that enabled them to reach out with information about their activities. Additionally, they needed meeting places and a distributor that could provide them with the corresponding kind of knowledge. Aarhus Book Cafe would be that knowledge base, or communications centre, for the phenomenon he described as the counterculture of the time.

One of the founders of the Book Cafe in Lund explained that the idea behind the project came from a deeply felt need to be able to read current political, philosophical, and literary theory with a Marxist touch, as well as a reaction against the unwillingness of the traditional bookshops to market these texts. ${ }^{17}$

Literature researcher Henning Olsen paints the breeding ground of the Danish book cafe movement in a similar vein in his 1980 study on the book market of the Danish New Left. Here, Olsen describes the emergence of small leftist presses and publishers as a result of this development, such as Demos or 
Modtryk, in which young activists looked upon established publishers as part of a hegemonic public or "establishment" against which they wanted to revolt. ${ }^{18}$

One attribute that united a large part of the New Left was a suspiciousness of the view of reality prevalent in the mass media, in the big large newspapers, TV, and radio. With inspiration from thinkers such as Herbert Marcuse and Antonio Gramsci, they talked about being estranged from and passivised by the political system. The activists sought to form new, alternative ways of communication to channel the kind of political knowledge upon which the movement was based. Central to this knowledge were the concepts of "antiauthoritarianism" and "participatory democracy". ${ }^{19}$ In line with contemporary slogans such as "the personal is political" followed a belief that one's political conviction should permeate every area of life and was not to be surrendered to established political authorities. ${ }^{20}$ The solution was formulated as a kind of participatory democracy, the conviction that one's everyday actions would eventually lead to liberation. Instead of waiting for the slow political mills to grind, a "cando" attitude took root. This novel political culture included patterns of action and organisation. ${ }^{21}$ However, a crucial aspect for the book cafe activists was their ambition to break through the boundaries of their own subculture and to introduce their ideas and knowledge to the surrounding society. As such, they acted as true representatives of a counterpublic, as Fraser imagines them: "In my view, the concept of a counterpublic militates in the long run against separatism because it assumes an orientation that is publicist." The whole point of the book cafes was to "disseminate one's discourse into ever widening arenas", as Fraser puts it. ${ }^{22}$

\section{Revolting against the established book market}

In the television broadcast referred to at the beginning of this chapter, the Book Cafe in Lund was presented as an example of how the conditions for bookselling had changed due to the deregulation of the Swedish book market in 1970. In short, this deregulation implied that the so-called commission system prevailing for more than 130 years would be replaced by a system of free competition. This was a remarkable change for a national book market up until that point characterised by tradition and conservatism. ${ }^{23}$

Before 1970, the Swedish publishers' association had the privilege to control which bookshops should be established, as well as guaranteeing these establishments the exclusive right to sell books above a certain price limit. Due to the deregulation, the fixed book prices constituting the basis of the old system were revoked. From now on, anyone had the right to sell books and the retailers, not the producers, set the prices. Thus, it became possible to start bookshops specialising in individual genres, as well as for retailers to choose freely from the book lists of all Swedish publishers. ${ }^{24}$

In Denmark, the situation was different. During the 1960s and 1970s, the Danish book market was still strictly regulated. Bookshops privileged by the publishers' association gained a special position with respect to selling books 
from publishers that were under the rules set by the association, the so-called "bookshop monopoly". ${ }^{25}$ Consequently, the Danish regulatory framework had the effect that bookshops could not sell books at discounted prices unless this had been sanctioned from above. When the first Danish book cafes were established in the early 1970s, this meant that the rules for book sales in Denmark were challenged in an obvious way. ${ }^{26}$

The first Danish book cafe of significance started in 1970 as part of a government-funded project, The House, in central Copenhagen. The House was an all-activity house in which the bookshop was a part. The book cafe of The House would be an important source of inspiration for the founders of Aarhus Book Cafe, which was established in 1971 by activists united in the fight against Danish housing policy. ${ }^{27}$ Another important role model was the Book Cafe in Lund but also German and French predecessors. ${ }^{28}$ The enterprise was initially not categorised as bookseller but as a "kiosk". This meant that it was limited to selling imported books, media material from alternative publishers, and books from established publishers that cost less than a set limit of 17.25 kroner (which in practice meant paperback books). There were some benefits associated with being a shop that was not affiliated with the established system. For example, Aarhus Book Cafe could sell imported books at a lower price than a traditional bookshop, as it had not signed the publisher's agreement. ${ }^{29}$

Almost none of the Danish Book cafes were categorised as bookshops by the publishers' association. ${ }^{30}$ These circumstances had an effect not only on the prices of books but also on the genres available for sale. Due to a rule that allowed stores other than bookshops to sell books on closely related themes (e.g., books about dogs could be sold in pet shops), book cafes could subsequently negotiate better terms for books on economical and political topics. However, there was no exemption for the sale of fiction. ${ }^{31}$

\section{Political knowledge within the New Left in Sweden and Denmark}

The Book Cafe in Stockholm was established in 1973.

We sell books, magazines, posters, postcards and gramophone records.

We also work with study groups, debate evenings and lectures.

The main purpose is to promote the knowledge [emphasis added] of the crisis of capitalism and the situation of the working class. ${ }^{32}$

Thus, the point of departure and direction for Book Cafe Morianen in Stockholm was formulated in a policy statement from May 1975. This statement is particularly interesting in this context, as it provides an illustrative example of the perception of knowledge within the enterprise in question. Knowledge dissemination is mentioned as the main purpose and focus of the book cafe, while no concrete description is given, except for a few standard phrases, as to what this knowledge is supposed to consist of. 
On the other hand, how the knowledge dissemination was to be initiated was described in more detail, namely by media distribution, activism, and education. By means of activities such as study groups, debate evenings, and lectures, the theoretical knowledge expressed in books and bulletins should be put into practice and thus become part of the participatory democracy at the basis of the entire knowledge concept of the New Left. In the continued description of the enterprise, the political objective of the book cafe is formulated by listing different activities that had been initiated in order to facilitate the promotion of such knowledge. Here, for instance, it was described how the books for sale in the book cafe were selected and how the selection was reviewed at recurring book meetings, open for all "active within the book cafe and interested partners". ${ }^{33}$ Genres for sale were "political theory and economy, countries and peoples, science and environment, progressive literature - modern and classic - within psychology, psychiatry, philosophy, pedagogy, prose and poetry". 34

The knowledge view permeating this and other policy statements from Morianen all have the same focus on openness. The ambition was to enable the circulation of a kind of knowledge that had previously been hard to find. ${ }^{35}$ As mentioned earlier, the three book cafes were all independent from political parties. In the archival material, this is repeatedly emphasised, as is their wish to be open to the surrounding environment rather than being closed and introverted. Knowledge was viewed as something created jointly, rather than theories to be studied in the same programmatic way by everyone. A playful example of this view of knowledge was expressed in the following reading instruction to the texts of Marx and Engels, published in one of the store catalogues of the Book Cafe in Lund:

There can be no talk of any detailed instructions, as long as you don't know the reader. Is he/she a communist seeking guidance in the struggle for the liberation of the proletariat? [. . . Is he/she a student sitting up at night, drinking French-roasted coffee, smoking Commerce and chasing a fitting view on life? Or perhaps an economics professor with a scholarship from SAF [the Swedish employers' association] and paid leave to disprove the lesson of class struggle? Of course, this is a question of widely different readings. ${ }^{36}$

\section{How the book cafes were organised}

Aarhus Book Cafe would become Denmark's oldest book cafe, substantially more long-lived than the other two cafes discussed here. During its first years, it was housed in a basement on Sjællandsgade, a side street between the university area and the city centre.

In a newspaper article from 1972, Aarhus Book Cafe was described as "neither a real bookshop nor a real cafe". ${ }^{37}$ Here, books, pamphlets, records, and posters were on sale, the author explained, but the customers could also have a 
cup of coffee or just sit down for a while and read a book or two in case they could not afford to buy them.

The political objectives were noticed not least in the basic rules of conduct formulated by Aarhus Book Cafe in various letters of intent written during its early years. It was here explained that the book cafe was not intended to be profitable and that all work should be performed on a voluntary basis. The power structure was flat and based on the premise that all decisions were taken jointly at weekly meetings, the so-called "general assemblies". In these meetings, everything from issues of order, the selection of literature, and how to deal with publishers to issues of a more ideological nature was discussed. A few guidelines formulated in the early 1970 s read as follows:

The purpose of the enterprise is to run a book cafe that will function as the left-wing bookshop in Aarhus, independent of political organisations, where you will always be able to get hold of the books you need in your political work, studies, etc. ${ }^{38}$

It was further announced that it was a self-taught task of the book cafe to offer "theoretical conditions for the struggle for socialism by the working class". 39

The people behind the book cafe were all linked to Aarhus University in one way or another, as teachers or as current or former students (among the latter, for example, journalists and social workers). The economic investment was made possible through a cooperative where you could buy shares for 10 kroner each. ${ }^{40}$

The book cafes in Lund and Stockholm had a similar organisational structure. They were both organised as limited companies in which people who sympathised with the basic values of the enterprise could buy shares. These "guaranteed dividend-free" shares offered voting rights at annual general meetings. ${ }^{41}$ While the majority of the people behind the two Swedish enterprises were politically active students and graduates, this did not apply to the whole staff. Something they all had in common, in addition to some kind of left-wing view, was a willingness to work for a low wage for a goal they believed in. ${ }^{42}$

In terms of the view on paid work, there were differences between the enterprises. While Aarhus Book Cafe was totally dependent on unsalaried workers, Morianen in Stockholm had the ambition to pay a low salary to its employees, regardless of position. ${ }^{43}$ The Book Cafe in Lund only had a small core of paid employees. The enterprise partly depended on a large network of volunteers who could be called in when needed. All three book cafes made an effort to maintain a flat organisational structure. A large part of the activities was performed in various working groups responsible for things such as ordering books, the cafeteria, or new recruitments. The striving for a kind of solidarity in practice is clearly noticeable in the printed material forming the main empirical foundation of this chapter. 


\section{Alternative media production}

Magazines and bulletins are the necessary complements to established mass media, which often lack information and depth in the political, economic and social fields. We also offer a large number of Swedish and foreign journals. ${ }^{44}$

In an unprinted newsletter from Book Cafe Morianen, arguments were made for magazines and bulletins as a necessary complement to the "established mass media", which were considered insufficient in terms of providing current knowledge on relevant social issues.

At a time when traditional media as a knowledge channel are increasingly questioned by people at the very core of the international political establishment, and when this establishment is increasingly found on the political right, it is interesting to note how their line of argument is formulated almost verbatim as the New Left activists did in the 1970s. ${ }^{45}$

In Philipp Felsch's Der lange Sommer der Theorie. Geschichte einer Revolte 1960-1990, a study that can be described as a book history of political theory as a genre, the author shows how this genre could gain a key position in the political revolt and youth culture of the 1960s. Felsch argues that the popular paperback format in itself was an important factor in the distribution and circulation of texts that formed the canon of this movement, such as the works by Herbert Marcuse and the Frankfurt School. ${ }^{46}$

Henning Olsen, who carried out a comprehensive survey of Denmark's leftwing publishers and book cafes during the 1970s, states that these actors saw the production of non-fiction as an end in itself, as well as a kind of practical political work. This is a perception of knowledge that also fits in well with the idea behind the book cafes. ${ }^{47}$ Olsen points out how not only the media producers and distributors were new but also that the media formats gained a new shape or even exchanged expressions in better harmony with contemporary ideals of self-determination and non-professionalism. Typewritten and mimeographed bulletins and pamphlets were only two of the new media formats that became essential in the knowledge circulation of the New Left movement. These techniques could also be used for book production by some small alternative publishers, although the use of professional printers was the most common. ${ }^{48}$ As Olsen writes, the price question was a decisive factor for the choice of this form of production, although necessity was commonly seen as a virtue and cheap production was promoted as a political standpoint. ${ }^{49}$ Old but easyto-use techniques such as silkscreen printing became popular for illustrations and cover art of pamphlets and records. Even the aesthetics were influenced by this approach, inspired by, for example, underground comics and poster art from the Russian Revolution. ${ }^{50}$

Of the three examples studied here, the Book Cafe in Lund was the most ambitious enterprise from this point of view. Far from being just a distributor, it had its own production of printed matter of both simple and more 
expensive kinds. The book cafe's warehouse catalogues listed all the books and printed matter marketed. These catalogues were published on three occasions: 1973/1974, 1977/78, and 1982/1983. In addition to lists of books, they also included subject-based reviews written by people in the circle around the cafe. The purpose of these catalogues was to serve as bibliographic manuals but also to "be used for literature selection for courses for schools and universities, for study circles and providing impulses and ideas for your own reading". ${ }^{51}$

A large part of the Book Cafe in Lund's sales consisted of mail order. On the basis of this activity, a monthly magazine, called Bokcaféts Månadsbulletin [The Book Cafe's Monthly Bulletin], was produced between 1974 and 1982. Here, new books were listed according to categories such as "Marx/Engels", "Sociology", "Women's Liberation", and "Africa". In addition, new literature was reviewed and discussed on topics such as "The United States of America", "The Danish Student Movement", and "Children's Books". ${ }^{52}$ The writers included well-known profiles from Lund's academic left, such as Svante Nordin and Göran Therborn, as well as unskilled activists for whom The Monthly Bulletin served as a nursery. ${ }^{53}$ To a contemporary reader, the articles in the The Monthly Bulletin come across as noticeably undogmatic. The tone is considerably different from that of the categorical and literary internal debate that was conducted in, for example, the newspapers of Swedish Maoist groups in the 1970s. The editorial material of these magazines offers the reader a rather profound insight into the political and literary debate within a circle of leftist Swedish students, academics, and other interested parties during a politically dynamic decade. It also provides an insight into which political theories, societal, literary, and philosophical questions - which kind of knowledge - were considered relevant in a wider intellectual arena during the same time period. ${ }^{54}$

\section{The bookshop as social space and knowledge arena}

In a brochure printed in connection with the opening of Book Cafe Morianen in 1973, the cafe was presented as "more than a bookshop and a coffee shop". ${ }^{55}$ Those who could not afford to buy a book could borrow a reading copy, and the staff planned for both a children's playroom and study circles for knowledge-impaired adults. The objective was to support people's knowledge acquisition, based on a pronounced socialist approach.

For the book cafes in Stockholm and Lund, the cafe part of the enterprise was indispensable. It was considered the basis for activities that would "provide an opportunity for overview and analysis, ${ }^{56}$ as formulated in a statement from Morianen. According to the original plan, the cafeteria would provide a "meeting place and discussion site", ${ }^{57}$

The Book Cafe in Lund described its cafe activities as part of the effort to "try to create and form a spiritual/physical communication centre for the progressive and socialist movement in Lund with surroundings" by providing "a place for intense discussions and [. . .] magazine reading". ${ }^{58}$ The objective of both activities is obvious; they aimed to present an arena for articulating, 
circulating, and exercising knowledge and thus direct it "toward wider audiences" (i.e., to make it a public commodity). ${ }^{59}$

In this eagerness to form a space for knowledge exchange, the socialist book cafes were linked to a long historical tradition. As shown in an article by media historian Johan Jarlbrink on the 19th-century cafe Blanche in Stockholm, a meeting place for unmarried men from the bourgeoisie, the cafe environment as such organised the guests' media consumption through its architecture, furnishing, and lighting. ${ }^{60}$ Here, they could enjoy a good meal, hang out, and read newspapers, while having the opportunity to take part in the more or less public conversation. By simultaneously serving as social venues and media distribution centres, cafes such as Blanche served as breeding grounds for new political, social, and cultural ideas - in other words, as a kind of knowledge arenas. It is interesting to note that the book cafes in Lund and Stockholm played a similar role in their respective contexts.

The case of Aarhus Book Cafe, however, looked somewhat different. In the preserved archival material, there was a recurring discussion on how to understand the "cafe" part of the concept of book cafe. In an internal letter, the signature "Asger" feared the bad quality of the coffee-related activities:

No, the current status of the cafe in BC [Book Cafe] has to be expanded, today it is only represented by breadsticks (something that only reminds me of the bizarre bachelor furniture or typical kitchen situations from collectives) and a coffee machine in a corner, which, moreover, needs to be descaled, as well as plastic cups, some of the worst capitalist synthetic piss there is. ${ }^{61}$

More than forty years later, two of the activists behind Aarhus Book Cafe argue that the enterprise was, in essence, a bookshop, with the addition that there was a coffee machine in one corner:

Book cafe, the term, you can't really understand it today. It was the same as in Germany and Sweden. There was Lund's book cafe and so on. The name indicated a left-wing book brokerage policy. So, there is not much in the "cafe" part of the name. ${ }^{62}$

The quote states that "cafe" as part of the name of this enterprise, first and foremost, signalled a certain political orientation, as well as participating in the long tradition of cafes as places of knowledge circulation, which is also discussed in Jarlbrink's article.

There is remarkably little research published on the historical role of bookshops as such spaces at the intersection of culture and commerce. One exception is the anthology The Rise of the Modernist Bookshop, published in 2015 and edited by Huw Osborne. ${ }^{63}$ Here, several authors discuss the bookshop as a social space and co-creator of literary culture. Osborne describes small and independent bookshops as focal points where aesthetic and cultural ideals merged with social and political aspirations, while at the same time dependent 
on an economic reality. Many bookshops of this kind - The Sunwise Turn in Manhattan and The Progressive Bookshop in London are two examples discussed in the book - seem to have existed in a constant state of denial regarding economic constraints. ${ }^{64}$ Osborne's anthology shows how the view of literature and the human encounter that counteracts society's commercialisation has been a common driving force of independent bookshops throughout history. What may seem like a paradoxical meeting between business and anticommercialism could, in fact, become a momentum for these bookshops. The book cafes discussed in this chapter represent three more recent examples of the same phenomenon.

\section{Political knowledge circulation}

The mail order service Bokbäraren (the Book Carrier) was an alternative book distribution agency launched in 1976 by people behind the Book Cafe in Lund. It was a cheeky initiative based on a deep frustration with the giant Swedish distribution company Seelig \& Co, which enjoyed a national monopoly seen by the Book Cafe activists as "a threat against the freedom of the press". ${ }^{65}$ Seelig's distribution network was not used by all Swedish booksellers (for instance, many left-wing booksellers did not belong), making it hard for publishers that wanted to sell their books there. Bokbäraren was intended to be particularly useful for those publishers, freeing them from the need to sign up for unprofitable distribution.

Bokbäraren may be viewed as a hub within an alternative network of political knowledge, operated not only by and between the three book cafes in question but by a large number of actors and institutions, both producers and retailers. The distribution network soon comprised 500 booksellers across Scandinavia, including almost all left-wing booksellers. ${ }^{66}$ This was especially true of Morianen in Stockholm, which frequently used its sister service in order to order books in other languages, not least German. ${ }^{67}$

Archival material from Aarhus Book Cafe shows that they had considerable use for Bokbäraren's mail order, especially in the early years, with regard to literature from countries outside of Scandinavia. Swedish political literature was also bought from Lund to the Danish book cafe. It is also evident that Swedish music records were sought after in both Swedish and Danish book cafes. For example, the record company Music Network Corps, located in Vaxholm outside Stockholm and known for introducing "progressive" rock bands such as Gunder Hägg and Nationalteatern, collaborated with all three book cafes.

In a statement from the Aarhus Book Cafe, the purpose of its activities was formulated as follows:

Finally, the book cafe is to be seen as part of the construction of an alternative Danish distribution system for political literature. This is achieved through an affordable dissemination of material from alternative Danish and foreign publishers. ${ }^{68}$ 
They thus intended to be part of an alternative distribution system within the Danish book trade, focusing on political texts. As the quote shows, there was an interest in information from other countries and foreign publishers, while the focus of their own activities was primarily directed inwards, towards Denmark.

Something that clearly distinguishes Danish conditions from those in Sweden was that in 1978, internal relations in Denmark were raised to a higher organised level through the formation of Book Cafes in Denmark (BID). This organisation gathered all types of left-wing booksellers in Denmark, from the very small shops linked to, for instance, the Trotskyist movement to large party-independent enterprises such as the Aarhus Book Cafe. By the end of the 1970s, about sixty Danish book cafes were affiliated with the organisation, which aimed to safeguard its members' interests vis-à-vis the publishers. They published joint product catalogues and also negotiated with the Danish alternative small presses to gain favourable terms for the book cafes in a kind of alternative book trade agreement. ${ }^{69}$

At the same time as the book cafes presented their own enterprise as a response to a demand from a specific customer group, the focus was always on both widening this customer group and reaching out to larger segments of society. Both Morianen in Stockholm and the Book Cafe in Lund were located in the most central parts of the city. In addition to their own outward-facing activities, such as bookselling, study circles, and the production of bulletins and flyers, the book cafes were often discussed in the established Swedish mass media. Reporting on the book cafes was done not only in public service television but also in radio broadcasts and newspapers. When, in the mid-1970s, Morianen was threatened with closure due to the decision by the authorities to demolish the entire city block, this was noted by all the major newspapers. ${ }^{70}$

It is noteworthy that as it progressed in both Sweden and Denmark, the book cafe movement appears to have been simultaneously provincial and international. Their outlook on the outside world was primarily concerned with an interest in contemporary political literature, whether written in any of the Nordic languages, English, German, or French. As far as cross-border cooperation was concerned, both Swedish and Danish activists express that this became less common over time. Activists from the book cafes in Stockholm and Aarhus alike mention the Book Cafe in Lund as a model and inspiration in terms of organisational forms and methods for ordering and purchasing literature. ${ }^{71}$

Within the scope of the book cafes' activities, several practices were undertaken that could be gathered under the term "popular education". This concept calls for various types of volunteer education that are out of state control and traditional academic contexts. Swedish researcher Staffan Larsson has pointed out that venues for popular education, such as study associations, have historically served as "experimental workshops" that introduced new types of knowledge to groups that often lacked a traditional educational background. Thus, these activities played the role of disseminators of knowledge to wider groups of society. ${ }^{72}$ It is obvious that the book cafes had a similar function within their specific historical context. 


\section{Conclusion: an alternative system of knowledge circulation}

The concept of "public knowledge" is crucial for understanding the dissemination of information carried out by the book cafes. The very breeding ground for their activities was a thirst for knowledge and the experience of being excluded from the same by the traditional channels.

"Knowledge is always evolving, changing and 'realizing' through circulation between different societal spheres", Sarasin argues. ${ }^{73}$ The three book cafes analysed in this chapter constitute a clear example of how such societal knowledge circulation has historically worked in practice. The book cafes, sometimes in a processed form, distributed a kind of knowledge that previously belonged to the universities in order to make it part of the public domain. At the same time, their activists traded their knowledge in practice through a series of positions regarding distribution methods, division of work, and other knowledge-sharing activities.

With their large network of contacts, the Scandinavian book cafes took on key roles in the distribution of left-wing literature, magazines, flyers, and other printed matter of both an ideological and an academic nature. They served as display windows for a new, alternative market for political literature and other media material, which existed partly outside the established institutions. I argue that the book cafes in Lund, Stockholm, and Aarhus had an important, albeit not previously examined, role in the process of transforming these and other related texts into what James Secord refers to as "a part of the taken for granted understanding of much wider groups of people". ${ }^{74}$

In this, they may be seen as links in a Scandinavian tradition of popular education that looked upon knowledge as a means for the individual to gain access to co-determination and power over one's own role as a citizen. ${ }^{75}$ Another way of putting it is that the three book cafes served as nodes in an alternative circulation system of public knowledge. This circulation was crucial for the emerging political mass movement known as the New Left in Denmark and Sweden. As they operated independent of political groups, parties, or institutions, they sought to represent the whole spectrum of knowledge within the New Left, as well as to take an active part in making it part of the public domain.

The critique of an established "system", politically as well as in terms of the media and book market, combined with a confident "can-do attitude" were pivotal for the knowledge constituting the circulation where the book cafes served as arenas for production, dissemination, and consumption.

Through their dialectic role as bases for both inward and outward knowledge activities, the book cafes served as constitutive parts of a wider counterpublic in the sense of how Fraser defines the concept. Scholars researching the print and media cultures of the New Left have emphasised how the activities within the movement constituted a counterpublic characterised by interactivity and co-determination, as well as by the critique of traditional mass media. ${ }^{76}$ This attitude enabled things such as mass demonstrations, street theatre, and the 
production of protest music and print, but also the emergence of socialist book cafes as nodes of an alternative system of societal knowledge circulation. ${ }^{77}$

\section{Notes}

This chapter presents research funded by the Knut and Alice Wallenberg Foundation and the Carl Cederblad's Memorial Fund.

1 See Kathrin Fahlenbrach, Erling Sivertsen, and Rolf Werenskjold, "Introduction: Media and Protest Movements", in Media and Revolt: Strategies and Performances From the 1960s to the Present, eds. Kathrin Fahlenbrach, Erling Sivertsen, and Rolf Werenskjold (New York: Berghahn, 2016), 1-2; cf. Kathrin Fahlenbrach, Protest-Inszenierungen: Visuelle Kommunikation und kollektive Identitäten in Protestbewegungen (Wiesbaden: Springer VS, 2000); Ingo Cornils, Writing the Revolution: The Construction of '1968' in Germany (Rochester, NY: Camden House, 2016), 151-152.

2 Kathrin Fahlenbrach, "Protestinszenierungen: Die Studentenbewegung im Spannungsfeld von Kultur-Revolution und Medien-Evolution", in Handbuch 1968 zur Kultur- und Mediengeschichte der Studentbewegung, eds. Martin Klimke and Joachim Scharloth (Stuttgart: Metzler Verlag, 2007), 14.

3 Cf. Ragni Svensson, "Bokcafét: Politisk och social mötesplats i 1970-talets 'röda Lund"”, Biblis 72 (2015): 62-69.

4 Uwe Sonnenberg, Von Marx zum Maulwurf: Linker Buchhandel in Westdeutschland in den 1970er Jahren (Göttingen: Wallstein, 2016), 126-130; Lisa Borgemeister, "Politische Buchhandlungen im Kontext mit der 68er Bewegung ind der BRD - Am Beispiel der Marburger Buchhandlung 'Roter Stern'”, in Die Politisierung des Buchmarkts: 1968 als Branchenereignis, ed. Stephan Füssel (Mainz: Harrassowitz, 2007); Kristin Ross, May,'68 and Its Afterlives (Chicago: University of Chicago Press, 2002), 83.

5 Lennart Nylund, “Men vad hände med alla vänsterpolitiska boklådor?” Svensk Bokhandel 4 (2001): 23-25.

6 Sven-Olof Josefsson, “Året var 1968: Universitetskris och studentrevolt i Stockholm och Lund" (PhD diss., University of Gothenburg, 1996), 11-12.

7 Philipp Sarasin, "Was ist Wissensgeschichte?" Internationales Archiv für Sozialgeschichte der deutschen Literatur 36, no. 1 (2011): 166 [author's translation].

8 Simone Lässig, "The History of Knowledge and the Expansion of the Historical Research Agenda", Bulletin of the German Historical Institute 59 (2016): 35.

9 Josefsson, "Året var 1968”, 28.

10 Johan Östling and David Larsson Heidenblad, "Cirkulation - ett kunskapshistoriskt nyckelbegrepp", Historisk Tidskrift 137, no. 2 (2017): 279.

11 Andreas W. Daum, "Varieties of Popular Science and the Transformations of Public Knowledge: Some Historical Reflections”, Isis 100 (2009): 321; James Secord, "Knowledge in Transit", Isis 95 (2004): 655.

12 Östling and Larsson Heidenblad, "Cirkulation”, 284.

13 Ibid., 279.

14 Nancy Fraser, "Rethinking the Public Sphere: A Contribution to the Critique of Actually Existing Democracy", Social Text 25/26 (1990): 61.

15 John McMillian, Smoking Typewriters: The Sixties Underground Press and the Rise of Alternative Media in America (New York: Oxford University Press, 2011), 4.

16 Arne Hald, Interview by Ragni Svensson, Aarhus, 7 November 2018.

17 Gunnar Olofsson, Interview by Ragni Svensson, Lund, 7 November 2015.

18 Henning Olsen, "Venstrefløjens bogmarked: Forlag og bogcafeer 1968-79" (PhD diss., Aarhus University, 1980), 16-18; cf. McMillian, Smoking Typewriters, 5.

19 Josefsson, "Året var 1968", 31; Olsen, "Venstrefløjens bogmarked”, 18; Fahlenbrach, Sivertsen, and Werenskjold, "Introduction", 1. 
20 Cornils, Writing the Revolution, 57.

21 Josefsson, “Året var 1968”, 15; Olsen, "Venstrefløjens bogmarked”, 16; McMillian, Smoking Typewriters, 5 .

22 Fraser,"Rethinking the Public Sphere", 68.

23 Johan Svedjedal, "Kommissionssystemets epok - svensk bokbransch 1843-1970", in Bokbranschen i Sverige: Utvecklingen mellan 1973 och 2003: Rapport frän Svenska bokhandlareföreningen och Svenska förläggareföreningen (Stockholm: Svenska bokhandlareföreningen, 2003), 8-9.

24 Ibid., 8-9.

25 Jarl Borgen, Den faste bogladepris og dens kulturelle betydning (Copenhagen: Borgens forlag, 1973), 10; Bøger i Danmark: Bogudvalgets betankning, Betænkning nr. 969 (Copenhagen: Ministeriet for kulturelle anliggender, 1983), 91.

26 Olsen, "Venstrefløjens bogmarked", 85.

27 Interview Arne Hald 2018.

28 Søren Kristian Barsøe, Interview by Ragni Svensson, Aarhus, 7 November 2018.

29 Olsen, "Venstrefløjens bogmarked", 88.

30 According to the 1983 Danish governmental book market report, there were 17 left-wing book cafes and bookshops in Denmark in 1972. In 1973, the total figure had increased to about 60 and to 139 in 1978. Bøger i Danmark, 132.

31 Boger i Danmark, 132.

32 “Unprinted Statement from Bokcafé Morianen”, May 1975, Per Amnestål's Private Archive, Stockholm.

33 Ibid.

34 Ibid.

35 Another example is the following wording in a booklet from Bokcafe Morianen: "Our goal is to create an active bookshop with political literature and fiction that provides knowledge about the ways in which different societies work. We also want to cover the current social and leftist debate and report parts of it through, for example, theme displays and reviews". "Morianen har öppnat", Leaflet, 24 July 1973, Per Amnestål's Private Archive, Stockholm.

36 Elsa Svensson, "Läs Marx och Engels texter!" in Bokcaféts lagerkatalog 1973/74 (Lund: Lunds Bok \& Tidskrifts AB, 1972), 5.

37 "Sælger bøger over en kop kaffe", Hovedbladet, 1972.

38 "8 år med Ârhus Bogcafe", Leaflet, Aarhus Bogcafe's Archive, Aarhus University, Aarhus, 4.

39 Ibid., 4.

40 “De første år 1971-1973”, Aarhus Bogcafe's Archive, Aarhus University, Aarhus.

41 Bokcaféts lagerkatalog 1977/1978 (Lund: Lunds Bok \& Tidskrifts AB, 1976), 13.

42 Henrik Sampe, Interview by Ragni Svensson, Stockholm, 28 August 2018; Karin Lentz, Interview by Ragni Svensson, Åkarp, 12 May 2016.

43 Interview Henrik Sampe 2018; Interview Arne Hald 2018.

44 "Unprinted Statement from Bokcafé Morianen".

45 Cf.Johan Östling et al., "The History of Knowledge and the Circulation of Knowledge: An Introduction", in Circulation of Knowledge: Explorations in the History of Knowledge, eds. Johan Östling et al. (Lund: Nordic Academic Press, 2018), 10.

46 Philipp Felsch, Der lange Sommer der Theorie; Geschichte einer Revolte 1960-1990 (Munich: Verlag C. H. Beck, 2015).

47 Olsen, "Venstrefløjens bogmarked", 52.

48 Ibid., 56-58.

49 Ibid., 61.

50 Leif Nylén, "Inledning”, in Affischerna från den svenska alternativrörelsen 1967-1979, ed. Håkan Agnesäter (Stockholm: Ordalaget, 2013), 9.

51 Bokcaféts lagerkatalog 1973/74,1.

52 Ibid.

53 Cf. McMillian, Smoking Typewriters, 5. 
54 Cf. Lässig, "The History of Knowledge”, 33.

55 "Bokcafét Information", 1973, Per Amnestål's Private Archive, Stockholm.

56 "Unprinted Statement from Bokcafé Morianen".

57 Ibid.

58 Anonymous preface, Bokcaféts lagerkatalog 1977/1978,11.

59 Fraser, "Rethinking the Public Sphere", 68; cf. Daum, "Varieties of Popular Science", 329.

60 Johan Jarlbrink, "Lässcener: Publik och medier på café och sockenbibliotek", in 1800-talets mediesystem, eds. Jonas Harvard and Patrik Lundell (Stockholm: Mediehistoriskt arkiv, 2010), 44.

61 “Asger”, 1976-1977, Aarhus Bogcafe's Archive, Aarhus University, Aarhus.

62 Interview Arne Hald 2018; cf. Olsen, "Venstrefløjens bogmarked", 85.

63 Huw Osborne, ed., The Rise of the Modernist Bookshop: Books and the Commerce of Culture in the Twentieth Century (Farnham: Ashgate, 2015).

64 Ibid., 132.

65 Joachim Retzlaff, “Bokcaféts distributionsverksamhet”, Bokcaféts Månadsbulletin 10 (1976).

66 Ibid.

67 Interview Henrik Sampe 2018.

68 "8 år med Århus Bogcafe".

69 Bøger i Danmark, 133.

70 Lars Åberg, "Lokalbristen i Stockholm hot mot den fria kulturen”, Dagens Nyheter, 22 August 1977.

71 Interview Henrik Sampe 2018; Interview Arne Hald 2018.

72 Staffan Larsson, "Förnyelse som tradition", in Folkbildning - samtidig eller tidlös? Om innebörder över tid, eds. Anne-Marie Laginder and Inger Landström (Linköping: Mimer, 2005), 170.

73 Sarasin, "Was ist Wissensgeschichte?" [translation by Johan Östling in Johan Östling, "Vad är kunskapshistoria?" Historisk tidskrift 135, no. 1 (2015): 166].

74 Secord,"Knowledge in Transit", 655.

75 Lars Arvidsson, "Bildningsrevolutionen - hur gick den till?” in Folkbildning - samtidig eller tidlös? Om innebörder över tid, eds. Anne-Marie Laginder and Inger Landström (Linköping: Mimer, 2005), 15.

76 Fahlenbrach, "Protestinszenierungen",14.

77 Cf. Östling and Heidenblad,"Cirkulation”, 277. 